УДК 160.1

DOI https://doi.org/10.32837/apfs.v0i29.955

\author{
О. В. Павловська \\ ORCID ID: https://orcid.org/0000-0003-1594-2730 \\ кандидат філософських наук, доцент, \\ доцент кафедри філософії \\ факультету філософської освіти і науки \\ Національного педагогічного університету імені М. П. Драгоманова
}

\title{
ЛОГІКА ТА ДОЛОГІЧНЕ МИСЛЕННЯ
}

Концепція дологічного, або як ще його називають пралогічного мислення, вже стала досить відомою нині, а ії ідеї були сприйняті та розвинуті у багатьох напрямах сучасної гуманітарної науки. Терміни «пралогічне мислення» та «первісне мислення» давно увійшли у широкий вжиток. Проте сам термін, як і його сприйняття, досі викликає багато питань та багато інтерпретацій.

Слова «первинність» та «дологічність» у наведених словосполученнях мають досить умовний характер. Частим, але тривіальним витлумаченням первинності мислення постає його розуміння як мислення примітивнішого стосовно мислення сучасної людини. А інтерпретація понять дологічності та пралогічності доходить до ототожнення ï $з$ алогічністю взагалі. Однак якщо звернутися до синонімічного ряду поняття «первісне суспільство", що застосовується для позначення предмета етнографічних досліджень, а саме: «неісторичні народи», «племінні суспільства», «природні народи", то його витлумачення втрачає видимість такої простоти та однозначності. Останній термін особливо цікавий з позиції розгляду пралогічного мислення не як примітивнішого, а як того, що лише інакше орієнтоване.

Метою цієї статті є обґрунтування концепції, у межах якої дологічне мислення розглядається як особливий тип мислення та розкриття на цій основі деякої перспективи розгляду положення логіки у сучасній філософії.

Концепція дологічного мислення, як і самого поняття, була висунута французьким філософом Л. Леві-Брюлем як альтернатива анімістичній гіпотезі англійської антропологічної школи Е. Тайлора та Дж. Фрезера. Їх твердження про тотожність мисленнєвих процесів первісної людини та людини сучасного західного світу була визнана Леві-Брюлем методологічною помилкою. Дослідження пралогічного мислення французького філософа ставлять питання про сутність мислення як такого. А саме про те, чи є мислення незмінним, постійним та перманентним або воно може розвиватися і постає явищем історично мінливим. Леві-Брюль уперше показав, що мислення примітивної людини не збігається з механізмом мислення людини сучасної. Спробував визначити основні відмінності між ними та встановити найбільш загальні закони, яким підпорядкована діяльність дологічного мислення. Проте ствердження мінливості мислення та різниці між логіко-психологічним механізмом мислення первісної людини і людини сучасного світу, не привели автора до інтерпретації такого мислення як менш розвинутого і примітивного. Леві-Брюль пропонує погляд, відповідно до якого дологічне мислення - це мислення, що вибрало свій, відмітний шлях розвитку. Воно не менш розвинуте, але інакше підкорене власним законам та принципам. «Беручи за початкову точку чуттєві враження, які в первісних людей та у нас схожі один на одного, первісний менталітет робить різкий поворот і стає на шлях інший, аніж наш» [2, с. 352].

Найцікавішим тут є питання про те, що собою являють ці принципи. Першим і основним з них є принцип партиципації (причетності). Цей принцип може бути описаний таким чином. Одна й та сама істота або предмет може бути причетна до іншої настільки, що стає тотожною їй. У мисленні первісної людини предмети, істоти, явища одночасно можуть бути самими собою та чимось іншим. Інакше кажучи, для дологічного мислення протилежність між одиницею та множиною, між тотожним та іншим не вимагає обов'язкового заперечення одного з вказаних термінів, якщо стверджується інший та навпаки. Така неувага до закону суперечності обгрунтовується містичною спільністю, причетністю предметів. Містичність - це друга важлива характеристика дологічного мислення. «Первісний менталітет є у своїй основі містичним. Ця головна риса цілком пронизує те, як він судить, відчуває і діє. 3 цього випливає найбільша важкість зрозуміти його" [2, с. 352]. «Більшою мірою містичний, ніж логічний, менталітет первісних народів» [2, с. 337].

Логіка традиційно вважалася непридатним інструментом для аналізу містичного мислення. Навіть сьогодні залишається досить поширеною думка про те, що логіка і містика, як втілення строгої раціональності та повної ірраціональності відповідно, є антагоністами, що не мають і не можуть мати нічого спільного. Отже, є величезна прірва між дологічним мисленням та мисленням 
логічним. Особливо це виявляється у намаганнях здійснити логічний аналіз схем дологічного мислення. Втім деякі дослідження у цій сфері, зокрема робота Г.В. Гриненко, спрямовані на обгрунтування протилежної точки зору. Можливість здійснення логічного аналізу особливостей містичного мислення автор зумовлює дотриманням деяких методологічних передумов: 1) протилежність ірраціонального предмета дослідження і раціональних методів, які застосовуються в його аналізі, не виключає можливість та результативність проведення такого аналізу, якщо буде зафіксована обмеженість логічних методів та неабсолютність їх результатів: «...якщо наше джерело світла таке, що, як свічка або керосинова лампа, здатне висвітити тільки невелике коло предметів, це ще не причина, аби від нього взагалі відмовитися, сидіти та чекати сходу сонця, сподіваючись побачити відразу все, тим більше, що у світі $€$ і такі місця, куди сонячний промінь взагалі не здатний потрапити» $[1$, с. 6$]$; 2) можливість такого аналізу безпосередньо пов'язана 3 правильним визначенням предмета та цілей дослідження. Адже будь-яке дослідження такого роду своїм предметом розглядає не питання існування надприродних сил, а питання віри в існування таких феноменів. Базуючись на таких методологічних підставах, автор запропонувала грунтовний логіко-семіотичний аналіз містичного мислення.

Окрім закону партиципації та містичності дологічного мислення, важливим для його повнішої характеристики є й такі принципи, як принципи біолокації, інтуїції та причинності. Відповідно до принципу біолокації один і той самий предмет в один і той самий час може перебувати в абсолютно різних місцях. Виняткового значення набуває інтуїція в межах дологічного мислення. «Руку тубільця направляе щось на кшталт інтуїції, а вона, своєю чергою, керується ретельним наглядом за тими предметами, які являють для нього особливий інтерес» [2, с. 363]. Принцип причинно-наслідкового зв'язку, такий зрозумілий та очевидний для сучасної людини, набуває зовсім іншого характеру у межах мислення дологічного. Виявлення необхідних та достатніх умов явищ та виведення на їх основі законів цілком задовольняє мислення логічне і не потребує додаткових умов. Однак механізми дологічного мислення зовсім інші. «Можливо, що він (тубілець) виявив постійні антецеденти факту, що його цікавить, i в своїх діях він найповнішою мірою враховує свої спостереження. Однак реальну причину він завжди шукатиме у світі невидимих сил, за межами того, що ми називаємо природою, в «метафізиці» в буквальному сенсі слова» [2, с. 358-359].

Окремо слід зазначити й про такий важливий аспект, який є основою для формування та розуміння специфіки принципів і правил дологічного мислення, а саме мову. Мовні засоби, які настільки відрізняються від мови сучасної людини, постають формуючим елементом та одночасно тим бар'єром, який спотворює правильність сприйняття та витлумачення принципів дологічного мислення. «Для того щоб відчути нюанси в уявленнях тубільців, які іноді викликають у нас замішання, щоб "схопити» те, як ці уявлення зв'язуються один з одним у міфрах, оповіданнях i обрядах, необхідно, отже, досконало оволодіти духом і тонкощами мови» [2, с. 354].

Таким чином, Леві-Брюль, спираючись на археологічний матеріал, описує певний тип мислення, створює деяку цілісну концепцію мислення, яка може ігнорувати деякі закони формальної логіки, а замість них орієнтується на зовсім інші, іноді навіть протилежні закони. На грунті такої логіки у первісної людини складається зовсім інше уявлення про речі. Логіко-психологічні механізми дологічного мислення вкрай відрізняються від звичного мислення, підкореного традиційним законам логіки. «Його процеси протікають абсолютно іншим шляхом. Там, де ми шукаємо вторинні причини, намагаємося знайти стійкі попередні моменти (антецеденти), первісне мислення звертає увагу виключно на містичні причини, дію яких воно відчуває всюди. Воно без будь-яких труднощів припускає, що одна й та сама істота може одночасно перебувати у двох або декількох місцях. Воно підпорядковане закону партиципації (причетності), воно в цих випадках виявляє повну байдужість до суперечностей, яких не терпить наш розум» [3, с. 4].

Однак дологічне мислення, описане Леві-Брюлем, - це не певний початковий недорозвинутий рівень мислення сучасної людини. Логічне і дологічне мислення - це не стадії розвитку мислення, а різні типи мислення, що, зокрема, можуть цілком гармонійно співіснувати в одному й тому ж самому суспільстві. Елементи пралогічного мислення мають місце і в межах сучасного типу мислення. Тобто виведена автором концепція дологічного мислення, крім того археологічного підгрунтя, на основі якого вона була сформульована, може бути підтверджена й іншим матеріалом. I цей матеріал - це мислення сучасної людини з усіма їі особливостями та різноплановостями.

Питання про розрізнення типів мислення, про виокремлення різних схем раціональності набуло особливої актуальності у межах сучасної філософіï і логіки. На основі такої диференціації з'явилися напрями, які повністю ігнорують логіку та заперечують можливість побудови універсальної парадигми раціональності. Неприйняття основної філософської установки логічного позитивізму призвело до практично повної відмови від будьякої логіки. Особливо яскраво така негативна установка проявляється у постмодерністській філоcoфiї. Для постмодернізму властиве нехтування звичною логікою. Він вибудовує плюралістичні та 
мозаїчні моделі світу із характерною іронічністю стосовно всього, що відбувається. Йому не важлива точність, послідовність та доказовість. 3 точки зору постмодернізму настав час відмовитися від претензій щодо вироблення взагалі будь-якої універсальної парадигми раціональності.

Звичайно, що поняття «логічність» $\mathrm{i}$ «раціональність» - це не тотожні поняття. Зведення ж їх одне до одного суперечить, принаймні, факту існування ситуацій так званої «раціональної алогічності» (софізми) та «ірраціональної логічності» (парадокси). Традиційно логіка тлумачиться як дещо абсолютно «відірване» чи «очищене» від тих аспектів раціональності, які виходять за межі законів, принципів та методів ідеалізованих розмірковувань. Логічність, таким чином, розглядається як дещо позачасове. Звідси погляд на природу логічного може обмежуватися уявленнями про логіку як фрагмент математики або, принаймні, ствердженням того, що як тільки логіка вибудовує строгі формалізовані системи, вона «полишає сцену філософіï». Навіть сучасна логіка, як значне розширення традиційної, залишає незмінним свій внутрішній стрижень, незважаючи на констатування нових законів у межах нових систем логік. Разом із тим має місце тенденція у сучасній логіці, яка реалізувалась у розведенні понять формальної та неформальної логіки, де неформальна логіка (відповідно до одного зі своїх численних визначень) постає як «працююча логіка» (Ст. Тулмін) або «нова риторика» (Х. Перельман). «Для Тулміна головний недолік формальної логіки полягав у тому, що міркування, які використовувались у різних ситуаціях, остання зводила до універсальних стандартів, хоча самі стандарти мають залежати від тієї галузі знання, де їх використовують. На його думку, необхідно створити нову логіку, яка б наблизилася до епістемології та тим самим розширила б свій предмет за рахунок включення аргументативних процесів, що мають місце у різних ситуаціях людської життєдіяльності...» [7, с. 86]. Як бачимо, вже у роботах британського філософа робиться акцент на значному розрізненні поняття логічності у його класичному витлумаченні («ідеальна логіка універсальних стандартів») та понятті, яке завдяки своїй ситуативності та історичності розширюється до епістемології з претензією створити «нову логіку». Тому неформальна логіка будує моделі, які дозволяють доповнити критерії «ідеальної логічності» критеріями «раціональності реальних індивідів». Досліджуючи питання ментальних підстав діяльності, В.В. Навроцький також вказує на необхідність такого доповнення. «Більшість наявних підходів до перегляду переконань описують поведінку занадто ідеалізованих раціональних індивідів, які є досконалими у тому розумінні, що мають необмежені ресурси та ідеальну здатність розмірковувати. Поняття раціональності, задіяне в цих підходах, зазвичай пов'язане з класичною логікою, яка концентрувалась на формалізації «істин», що не мають винятків і зберігають цей статус у всі часи... Тому виникає потреба в інструментах моделювання свідомості менш ідеалізованих індивідів. Ці інструменти можуть бути запозичені із сучасної логіки і теорії аргументації. Їх застосування надає моделі, більш наближені до раціональності реальних індивідів» [4, с. 1].

Отже, сучасна логіка, доповнена «критеріями раціональності реальних індивідів», постає системою, що переосмислює "універсальні стандарти» логіки традиційної, активно реагуючи на зміни у стилі та способі наукового мислення. Тим самим у змістовому плані поняття логічності наближується до поняття раціональності, що постійно трансформується завдяки своїй історичності.

B.C. Стьопін, виокремивши три типи раціональності, звертає увагу на те, що «класичний тип раціональності концентрує увагу тільки на об’єкті і виносить за дужки те, що належить до суб'єкта і засобів діяльності. Для некласичної раціональності характерна ідея відносності об’єкта щодо засобів і операцій діяльності; експлікація цих засобів і операцій виступає умовою отримання істинного знання про об'єкт. Нарешті, постнекласична раціональність враховує співвіднесеність знань про об'єкт не тільки із засобами, а й із ціннісно-цільовими структурами діяльності» [6, с. 75]. Таким чином, поняття постнекласичної раціональності розширює аналіз діяльності, залучуючи до його змісту ціннісно-цільовий елемент, «...причому експлікується зв'язок внутрішньонаукових цілей з позанауковими, соціальними цінностями і цілями» [6, с. 635].

Таке розширення вказує на досить цікаве і не позбавлене дискусійного характеру питання про безумовний пріоритет раціонального пізнання перед дораціональними i позараціональними пізнавальними формами, що цілком корелює 3 питанням про пріоритет логічного стосовно дологічного та позалогічного мислення.

\section{Jimepamypa}

1. Гриненко Г.В. Сакральные тексты и сакральная коммуникация. Москва, 2000. 448 с.

2. Леви-Брюль Л. Первобытный менталитет. Санкт-Петербург, 2002. 400 с.

3. Леви-Брюль Л. Сверхъестественное в первобытном мышлении. Москва, 1994. 608 с.

4. Навроцький В.В. Логіко-семантичний аналіз інформаційних і мотиваційних підстав соціальних дій : автореф. дис. ... док. філос. : 09.00.06.Київ, 2010. 32 c.

5. Ракитов А.Н. Рациональность и теоретическое познание. Вопросы философии. 1993. № 11. С. 68-81.

6. Стёпин В.С. Теоретическое знание. Москва, 2000. $744 \mathrm{c}$.

7. Хоменко И.В. Теоретические проблемы неформальной логики: конфликты точек зрения. Гуманітарні студї. 2012. Вип. 15. С. 99-108. 


\section{Анотація}

Павловська О. В. Логіка та дологічне мислення. Стаття.

Дослідження містить аналіз проблеми визначення дологічного мислення, як воно представлене у концепції французького філософа Л. Леві-Брюля. Стверджується, що логіко-психологічні механізми дологічного мислення вкрай відрізняються від звичного мислення, підкореного традиційним законам логіки. Розкриваються основні принципи дологічного мислення, такі як принцип партиципації, містичності, а також принципи біолокації, інтуїції та причинності. Стверджується, що логічне і дологічне мислення - це не стадії розвитку мислення, а різні типи мислення, що можуть цілком гармонійно співіснувати в одному й тому ж самому суспільстві. Це обгрунтовується тим, що елементи пралогічного мислення цілком гармонійно вплетені у механізми сучасного типу мислення, яке, на відміну від дологічного мислення, ми називаємо логічним. Перед нами постає цілісна концепція мислення, яка може ігнорувати деякі закони формальної логіки, а замість них орієнтується на зовсім інші, іноді навіть протилежні закони. В межах сучасної філософії та логіки аналіз характерних рис дологічного мислення набуває особливої актуальності. Це пов'язано з деякими тенденціями у сучасній філософiї, зокрема з появою постмодернізму та його відмовою від побудови будь-якої універсальної раціональності і нехтуванням традиційною логікою. Типологізація мислення та виокремлення різних схем раціональності $€$ характерними операціями сучасної філософії. На основі таких диференціацій з'явилися напрями, які повністю ігнорують логіку та заперечують можливість побудови універсальної парадигми раціональності. Неприйняття основної філософської установки логічного позитивізму призвело до практично повної відмови від будь-якої логіки. Особливо яскраво така негативна установка проявляється у постмодерністській філософії. Аналіз принципів дологічного мислення є цікавим і з позиції сучасних тенденцій розвитку логіки та появою «працюючої логіки» або нової риторики, де постає необхідність у побудові моделей «раціональності реальних індивідів». Сучасна логіка, як значне розширення традиційної, залишає незмінним свій внутрішній стрижень, незважаючи на констатування нових законів у межах нових систем логік. Разом із тим має місце тенденція у сучасній логіці, яка реалізувалась у розведенні понять формальної та неформальної логіки, де неформальна логіка (відповідно до одного зі своїх численних визначень) постає як «працююча логіка» (Ст. Тулмін) або «нова риторика» (Х. Перельман). Аналіз принципів дологічного мислення, його значимість, результативність та відношення до логічного мислення вказує на цікаві перспективи у дослідженні питання пріоритету логічного і дологічного мислення; раціонального і дораціонального та позараціонального пізнання. Питання, яке у межах сучасної філософії та логіки набуває особливої актуальності.

Ключові слова: логічність, дологічне мислення, пралогічне мислення, раціональність, містичне мислення, партиципація, сучасна логіка, історичні типи раціональності, постмодернізм.

\section{Summary}

\section{Pavlovska O. V. Logic and prelogical thinking. -} Article.

The study contains an analysis of the defining prelogical thinking problem, as it is presented in the concept of the French philosopher L. Levi-Bruhl. It is said, that the logical and psychological mechanisms of the prelogical thinking are straight different from ordinary thinking, which is submitted to the traditional logic laws. There are revealing main principles of prelogical thinking, such as the principle of participation, mystery, and also principles of biolocation, intuition and causality. It is said, that the logical and prelogical thinking are not the thinking development stages, but they are the different types of thinking, that can be quite harmoniously combined in the same society. This is explained by the fact that the prelogical thinking elements are very harmoniously implemented to the mechanisms of modern thinking type, that different from prelogical thinking, we call logical thinking. Before us arise a whole concept of thinking that can ignore some formal logic laws, but instead of them use different, sometimes even opposite, laws. The analysis of prelogical thinking features in the modern philosophy and logic gets special importance. It is linked to some tendencies in modern philosophy, in particular with the appearance of postmodernism, with its refusal to construct any universal rationality and disregard of traditional logic. Thinking types and singling out different rationality schemes are the characteristic operations of modern philosophy. On the basis of such differentiations, have appeared some directions that completely ignore logic and deny the possibility of constructing a universal rationality paradigm. Non-acceptance of the basic philosophical view point of logical positivism has led to almost complete rejection of any logic. Such negative view point especially shows itself in postmodern philosophy. Analysis of the prelogical thinking principles is interesting from the position to the modern logic development tendencies and the appearance of "working logic" or new rhetoric, where there is need for building models of "rationality of real individuals". Modern logic, as a significant extension of the traditional logic, leaves unchanged self-inner core, despite the statement of new laws within the new logic systems. At the same time, there is a tendency in modern logic, which was realized in the separation of the formal and informal logic concepts, where informal logic (according to one of its many definitions) appears as "working logic" (Stephen Edelston Toulmin) or "new rhetoric" (Chaim Perelman). The analysis of the prelogical thinking principles, and its significance, effectiveness and attitude to logical thinking points to interesting perspectives in the study of the logical and prelogical thinking priority; rational, prerational and non-rational cognition. This question in modern philosophy and logic gets especial relevancy.

Key words: logic, prelogical thinking, pralogical thinking, rationality, mystical thinking, participation, modern logic, historical types of rationality, postmodernism. 